\title{
Dynamic properties during wood humidification
}

\author{
Martina Rudolfová ${ }^{1, a}$, Lucie Pitrová Netolická ${ }^{2}$, Zuzana Ferenčíková ${ }^{2}$, Tereza Váchová $^{1}$ and Radek Strnad $^{1}$ \\ ${ }^{1}$ Czech Metrology Institute (CMI), Radiová 3, Prague, Czech Republic \\ ${ }^{2}$ Czech Metrology Institute (CMI), Prümyslová 455, Pardubice, Czech Republic
}

\begin{abstract}
Measurement of the moisture in solid materials is important almost at all industry areas. Removing of the volatile substances is very important step before packing or selling wood items. Inaccurate moisture measurement may affect product quality, lifespan and its price. Large proportion of production processes depend on measurement or control of moisture in some form. Within SIB64 Metefnet project, time stability and moisture penetration dynamics of timber samples by gravimetric method and electrical moisture meters are investigated. Strong focus was oriented on penetration hygrometers, which are mostly used. Device for wood humidification was constructed. It allows multiple samples moistening at defined humidity levels with wet air flowing through chambers. Device consists of 3 chambers, where samples can be placed. In each chamber can be achieved different level of humidity. Moisture inside of samples is continuously measured with humidity sensors working on resistance principle. Different kind of wooden samples can be inserted in chambers and data are stored onto a computer. One of the motivations for construction of this device was increasing the speed of the wooden samples humidification. Nowadays used method of moistening in desiccator needs significantly more time. Article will describe device design and measurement results.
\end{abstract}

\section{Introduction}

Knowledge of the moisture content inside wood and wood products is essential for their proper handling and includes an important role in quality management system. Measurements are carrying out with hand held instruments based on different principles, e.g. change of the resistance or capacity. The repeatability of these instruments is poor and results are often user, application and usage dependent. Uncertainty of the calibration of this instrument is rather high and further knowledge about dynamics of moisture propagation in wood is needed. This paper is dealing with the development of the apparatus for an effective preparation of wood samples needed for calibration.

\section{State of the art}

The most commonly used method for wood moistening is usage of saturated solutions of acid salts in desiccators.

This method is time consuming, sample conditioning takes 6 weeks usually.

Regular checks of the moistening process and wooden samples are necessary during conditioning in desiccator, but this check disrupts climate inside the desiccator.

This process is long and can be harmful for health because of usage of the acid salts.

To reduce mentioned disadvantages, CMI developed equipment which accelerates the process of wood samples moistening and excludes influence of the acid salts to the human health.

\footnotetext{
${ }^{a}$ Corresponding author: mrudolfova@ $\mathrm{cmi} . c z$
}

\section{MEASUREMENT}

\subsection{Design of equipment}

Equipment for speed up moistening of wood samples and wood humidification on-line monitoring inside a cells was developed. The equipment was designed to speed up moistening process without opening the cells during measurements.

Apparatus compound of three cells where nine probes are placed and enables online record of the resistance to the PC. Dry air passes through the saturator where is moistened and afterwards fills whole area of the measuring cells. Big advantage of this device is possibility of different level of humidity in each cell (Figure 1). 


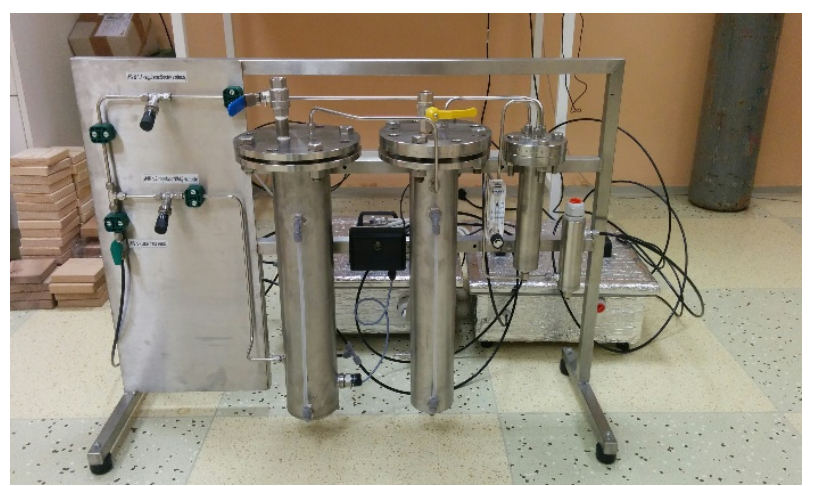

Figure 1: The skid for moistening of the wood samples. Consists of two saturators, humidity and air flow is also measured.

The design of the cells is shown in Figure 2. Three wood samples with resistivity probes installed into each sample are placed inside.

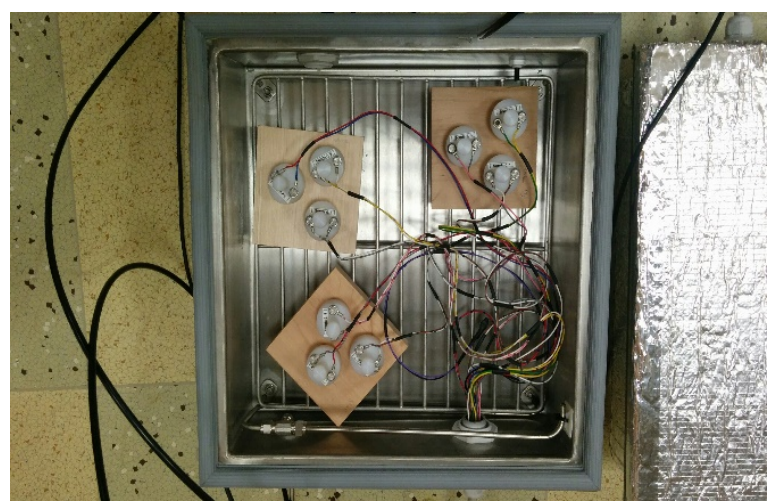

Figure 2: Cell with samples wood and probes

\subsection{Measurement procedure}

The measurements were carried out with three types of wood samples (beech, maple and alder). The size of the samples was selected according to standard [1]. Size of the tested samples was $(12 \times 12 \times 2.5) \mathrm{cm}$. In wood samples three probes were hammered to observe change of moisture during whole moistening process. Actual temperature and humidity inside cells can be also monitored with external probe during the whole moistening process. Wood samples were moistened and stabilized for 25 days. Figure 3 describes wetting duration for the beech wood. Similar trend was observed also for other two types of wood -maple and alder.

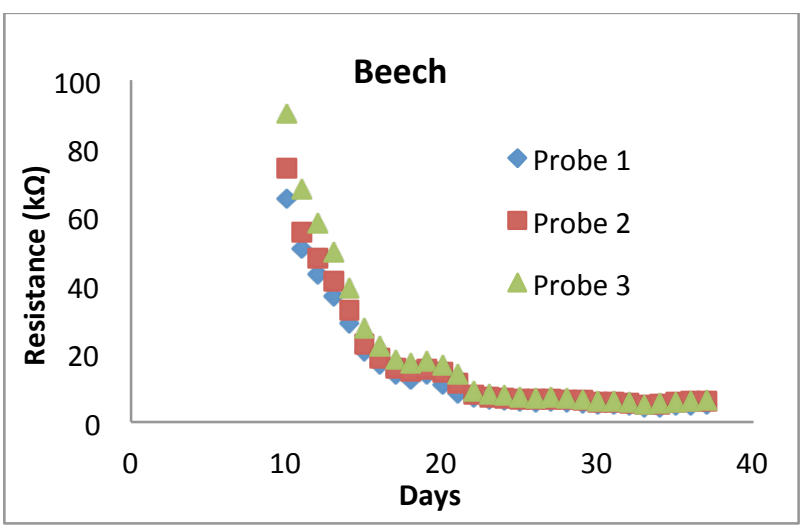

Figure 3: Time evaulation of moistening beech wood sample in cells

Each type of wood has its own maximum level of the humidity, which can be absorbed. When maximum level of the humidity is reached, level of the humidity inside the wood sample stays constant, no matter of the time which samples stay inside moistening cells.

Samples were taken out from the cells after finalisation of the moistening process. Humidity level inside the wood was measured with commonly used stick humidity probe suitable for the humidity measurement.

The following experiment was focused on the change of humidity in a cell and it influence on length of the wetting process.

Duration of the wetting process was investigated on the maple wood samples. Experiment no. 1 tries to identify necessary time to reach maximum level of the humidity inside a wood sample when relative humidity of air inside a cell was $90 \%$. Example no. 2 tries to identify this time when relative humidity of air was changed to the $80 \%$. Longer period which is necessary for moistening process in experiment no. 2 can be observed from Figure 4. Reason for this is lower moisture in air used for the sample humidification.

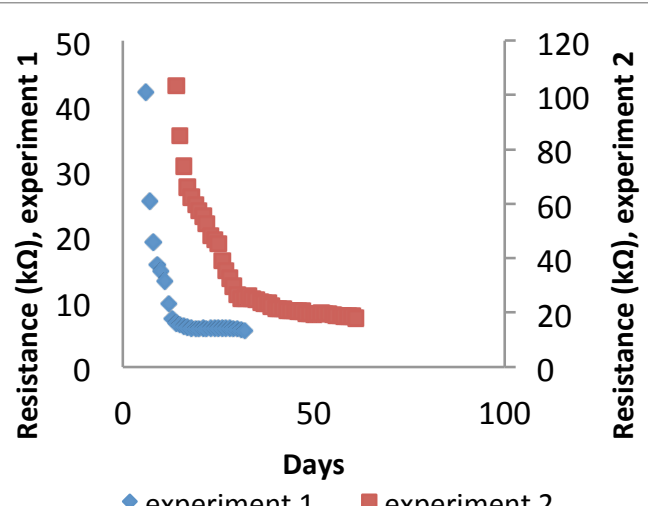

- experiment $1 . \quad$ experiment 2. 
Figure 4: Time evaulation of moisturing one maple wood sample at different air humiditiy level (90\% and $80 \%$ ).

Gravimetric method was also used for the measurement of the humidity level inside the wood samples. Comparison of the results obtained by using of mentioned methods is presented in a Table 1 .

\begin{tabular}{|c||ccccc|}
\hline Sample & $\begin{array}{c}\text { Dry } \\
\text { sample } \\
(\mathrm{g})\end{array}$ & $\begin{array}{c}\text { Wet } \\
\text { sample } \\
(\mathrm{g})\end{array}$ & $\begin{array}{c}\text { Net } \\
(\mathrm{g})\end{array}$ & $\begin{array}{c}\text { RH1 } \\
(\%)\end{array}$ & $\begin{array}{c}\text { RH2 } \\
(\%)\end{array}$ \\
\hline \hline Alder & 189 & 211 & 22 & 12 & 21 \\
Maple & 227 & 256 & 29 & 13 & 18 \\
Beech & 269 & 302 & 33 & 12 & 16 \\
\hline
\end{tabular}

Table 1: A comparison of moisture determination by gravimetric method (RH1) and standard probe (RH2).

Next experiment was focused on measurements repeatability. Six wooden samples ( 2 from each selected wood samples type) were placed inside a 2 measurement cells. Each cell contained 3 different wooden samples. Both cells were filled with air carrying the same level of the relative humidity. Length of the wetting process inside each cell in dependence on the wood type was investigated. Results confirm that wetting process has very similar behaviour in both measuring cells (table 2).

\begin{tabular}{|c|c|c|c|c|}
\hline & \multicolumn{2}{|c|}{ Experiment 1.} & \multicolumn{2}{|c|}{ Experiment 2.} \\
\hline Sample & $\begin{array}{l}\text { RH1 } \\
\text { (\%) }\end{array}$ & $\begin{array}{l}\mathrm{RH} 2 \\
\text { (\%) }\end{array}$ & $\begin{array}{l}\text { RH1 } \\
\text { (\%) }\end{array}$ & $\begin{array}{l}\mathrm{RH} 2 \\
\text { (\%) }\end{array}$ \\
\hline $\begin{array}{c}\text { Days of } \\
\text { moistening }\end{array}$ & \multicolumn{2}{|c|}{20 days } & \multicolumn{2}{|c|}{25 days } \\
\hline Alder & 12 & 18 & 12 & 20 \\
\hline Maple & 12 & 23 & 13 & 20 \\
\hline Beech & 10 & 18 & 12 & 21 \\
\hline
\end{tabular}

Table 2 : Measurements results of two repeated experiments for one air moisture level $(90 \%)$.

Wetting method using acid salts as a moistening medium shows significant differences in reached humidity level inside wood between single samples, which are placed together in a desiccator. Samples of same kind of the wood were placed in a desiccator. Humidity of all samples was measured from both sides and results are presented in Table 3. Different acid salts were used for different level of wood wetting. Results in a table 3 show variation in measured values.

\begin{tabular}{|c|c|c|c|c|c|c|}
\hline & \multicolumn{2}{|c|}{$\mathbf{N a C l}$} & \multicolumn{2}{c|}{$\mathbf{K}_{\mathbf{2}} \mathbf{S O}_{4}$} & \multicolumn{2}{|c|}{$\mathbf{K}_{\mathbf{2}} \mathbf{S O}_{\mathbf{4}}$} \\
\hline $\begin{array}{c}\text { Time of } \\
\text { conditioning }\end{array}$ & \multicolumn{2}{|c|}{$\mathbf{2}$ weeks } & \multicolumn{2}{|c|}{$\mathbf{4}$ weeks } & \multicolumn{2}{|c|}{$\mathbf{6}$ weeks } \\
\hline $\begin{array}{c}\text { Air humidity } \\
\text { in desiccator } \\
\text { (\%) }\end{array}$ & \multicolumn{2}{|c|}{75.8} & \multicolumn{2}{|c|}{96.9} & \multicolumn{2}{|c|}{96.9} \\
\hline \multirow{2}{*}{$\begin{array}{c}\text { RH1 } \\
\text { (\%) }\end{array}$} & 9.6 & 9.3 & 12.1 & 12.2 & 18.6 & 18.6 \\
\cline { 2 - 8 } & 12.2 & 12.4 & 12.2 & 12.5 & 18.9 & 19.0 \\
\cline { 2 - 8 } & 14.7 & 13.1 & 15.7 & 15.9 & 19.8 & 20.9 \\
\cline { 2 - 8 } & 15.3 & 15.5 & 17.12 & 18.9 & 22.9 & 21.9 \\
\cline { 2 - 7 } & 12.1 & 12.4 & 16.5 & 17.1 & 19.0 & 19.2 \\
\hline
\end{tabular}

Table 3: The repeatibility of the standard moisturing method.

Big advantage of the developed device is shortening of the wood samples moistening time in compare with classic method using desiccators. Moreover, it allows online monitoring of the samples moistening where no disruption of the conditions inside the cell is presented. Last but not least advantage is generation of different levels of the humidity in each cell.

It is necessary to take care about the presence of different microorganisms or fungi at the wood samples surface. These can influence measurement (moistening) process in a same way as a moistening in desiccators.

\section{CONCLUSION}

The device for easier and faster handling of the wood samples in process of humidity calibration of handheld equipment was developed. The metrological behaviour evaluation of new device was conducted. The results show that new device is quicker and with on-line moisture monitoring possibility in comparison to standard saturated salt methods. The comparison of repeatability and results compatibility was successfully performed.

\section{REFERENCES}

[1] http://www.oiml.org/en/files/pdf_r/r092e89.pdf, OIML R92 Wood-moisture meters Verification methods and equipment: general provisions. 